\title{
Friedrich Carl von Savigny tentang Hukum: Hukum sebagai Manifestasi Jiwa Bangsa
}

\author{
M. Zulfa Aulia \\ Fakultas Hukum Universitas Jambi \\ mzulfaaulia@unja.ac.id
}

\begin{abstract}
Friedrich Carl von Savigny was a legal figure with high reputation. He was recognized as a figure and the founder of the school of historical jurisprudence. This article attempts to discuss what he meant by law, how his thoughts about law began, and how these thought might have urgency and relevant to the present context. This article shows, Savigny's thought about law stems from his reflection on the development of law in civilized nations, that law grows naturally in society and is not deliberately made by certain (political) forces. Law is a part of social life that can be observed in the form of people's behavior and consciousness, as well as language and manners. It and other social aspects are united which arises from and reflects the spirit of the people (volksgeist) as well. Savigny's thoughts are urgent in a holistically placing law in society and building laws that have a continuity in the past, present, and future. Such thoughts become relevant in the current legal development of a country which tends to have a globaluniversal character, so that national law is reflected, harmonized, and colored by the spirit of the people.
\end{abstract}

Keywords: Savigny; legal development; people consciousness; the spirit of the people. 


\section{Zulfa Aulia}

\section{Abstrak}

Friedrich Carl von Savigny merupakan tokoh hukum dengan reputasi yang tinggi. Ia dikenali sebagai tokoh sekaligus pendiri aliran hukum sejarah (historicaljurisprudence). Dalam artikel ini dibahas apa yang dimaksudolehnya sebagai hukum, bagaimanakah pemikirannya tentang hukum bermula, dan, dalam konteks sekarang, bagaimana urgensi dan relevansinya. Artikel ini menunjukkan, pemikiran Savigny tentang hukum bermula dari refleksinya tentang perkembangan hukum pada bangsa-bangsa yang beradab, bahwa hukum itu tumbuh secara alamiah di masyarakat dan tidak dibuat secara sengaja oleh kekuatan (politik) tertentu. Hukum merupakan bagian dari kehidupan sosial yang dapat dilihat dalam wujud perilaku dan kesadaran masyarakat, seperti halnya bahasa dan tata krama. Hukum beserta aspek sosial lainnya itu merupakan satu kesatuan, yang muncul dan sekaligus mencerminkan jiwa rakyat atau bangsa (volksgeist). Pemikiran Savigny ini penting dalam mendudukkan hukum secara holistik di masyarakat dan membangun hukum yang memiliki kesinambungan masa lalu, kini, dan mendatang. Pemikiran demikian menjadi relevan dalam pembangunan hukum suatu negara saat ini yang cenderung berkarakter global-universal, agar dalam hukum nasional tetap tercermin, selaras, dan punya warna jiwa bangsa.

Kata kunci: Savigny; perkembangan hukum; kesadaran masyarakat; jiwa bangsa

\section{A. Pendahuluan}

Artikel ini memaparkan riwayat tokoh Friedrich Carl von Savigny dan mendiskusikan pemikirannya tentang hukum yang dikenali sebagai "hukum merupakan manifestasi dari volksgeist, jiwa bangsa". Pembahasan ini dilatarbelakangi oleh dua alasan: keberpengaruhan karya dan ketokohan Savigny. Pertama, Savigny menghasilkan karyakarya penting dalam studi hukum, terutama dalam tiga tulisannya: Das Recht des Besitzes (the Right of Possession), De la Vocation de notre siecle pour la legislation et la science du droit (The Vocation of our Age for Legislation and Jusrisprudence), dan The System of the Modern Roman Law. Karya-karya tersebut dalam perkembangannya menyebar luas: yang disebut pertama telah diterjemahkan ke dalam bahasa Italia, 
Perancis, dan Inggris; yang disebut kedua sudah dialihbahasakan ke bahasa Italia, Perancis, dan Inggris; dan yang disebut terakhir telah tersedia lebih dari 150 tahun dalam bahasa Inggris. ${ }^{1}$

Dari karya-karya tersebut lalu dipahami bahwa hukum merupakan penjelmaan atau manifestasi dari jiwa rakyat atau bangsa, volksgeist. Penjelasan hubungan keterkaitan dan keterikatan antara hukum dan jiwa bangsa dalam banyak literatur disebut sebagai hak cipta dari Savigny. Dalam artikel ini, sekalipun digunakan secara bergantian dengan jiwa rakyat, istilah jiwa bangsa lebih dipilih sebagai padanan volksgeist, yang merupakan istilah dalam bahasa Jerman, dan dalam bahasa Inggris, sebagaimana ditemukan dalam dua karya Savigny yang disebut terakhir tadi pada versi bahasa Inggris, disebut spirit of the people. ${ }^{2}$

Kedua, Savigny merupakan tokoh yang sangat berpengaruh dalam studi hukum terutama pada aliran atau mazhab yang dikategorikan hukum sejarah (historical school of law, historical jurisprudence). Aliran hukum sejarah sendiri adalah aliran hukum yang menafsirkan, menggambarkan, dan menjelaskan hubungan kompleks antara teori hukum dan historiografi. ${ }^{3}$ Dalam aliran hukum sejarah, Savigny kerap disebut sebagai penggagasnya. Pemikiran Savigny ini dalam perkembangannya menyebar luas dan turut memengaruhi perkembangan hukum dan pembelajaran hukum di berbagai belahan dunia. ${ }^{4}$ Di Indonesia, keberlakuan hukum adat menjadi mungkin

1 Herman Klenner, "Savigny’s Research Program of the Historical School of Law and its Intellectual Impact in $19^{\text {th }}$ Century Berlin”, The American Journal of Comparative Law, 37, 1 (1989), hlm. 67.

2 Penjelasan tentang jiwa bangsa sebagai padanan dari volksgeist ini, karena mengikuti uraian makna volksgeist, dapat dilihat nanti pada catatan kaki nomor 44.

3 William Twining, General Jurisprudence: Understanding Law from a Global Perspective (Cambridge: Cambridge University Press, 2009), hlm. 228. Dalam studi hukum, kata Twining di halaman yang sama, aliran hukum sejarah, bersama aliran hukum sosiologis (sociological jursiprudence), kerap dikategorikan sebagai aliran hukum yang melakukan penyelidikan teroretis tentang fenomena hukum aktual di "dunia nyata". Aliran hukum sejarah sendiri dalam perkembangan kemudian hampir secara eksklusif dikaitkan pada gagasan evolusi hukum.

4 Di negara berbahasa Inggris seperti Inggris dan Amerika, menurut Michael 
karena antara lain adanya pengaruh pemikiran hukum sejarah ini, baik pada masa kolonial maupun kemerdekaan. ${ }^{5}$

Oleh karena keberpengaruhan karya dan tokohnya tersebut, maka artikel ini yang mencoba membahasnya jelas berada pada baris belakangan di antara banyak artikellainnya yang sudah terlebih dahulu melakukannya, yang sebagiannya bahkan pada saat ini lebih banyak dibaca dan berpengaruh ketimbang karya asli dari tokohnya sendiri. ${ }^{6}$

H. Hoeflich, pendekatan historisnya Savigny terhadap hukum berdampak pada reformasi politik dan hukum (termasuk, tentu saja, kodifikasi) yang sangat penting dalam membentuk sikap para ahli hukum dan sarjana hukum di sana. Dampak dan tentu saja ketenaran Savigny ini dipandang Hoeflich tidak terlalu mengagetkan, sebab hubungan intelektual antara dunia berbahasa Jerman dan dunia berbahasa Inggris tidak jarang terjadi pada abad kesembilan belas. Jerman kala itu dipandang sebagai salah satu masyarakat paling berbudaya dan maju sehingga banyak yang bisa dipelajari. Jerman adalah tanah sastra dan musik, yang di situ ada Goethe dan Beethoven, dan sekarang juga hukum, dengan tokohnya Savginy. Michael H. Hoeflich, "Savigny and His Anglo-American Disciples", The American Journal of Comparative Law, 37, 1 (1989), hlm. 36-37.

5 Pada masa kolonial, pandangan Savigny tentang hukum dianut oleh Van Vollenhoven, Ter Harr, Holleman, dan lain-lain, sehingga hukum adat diberlakukan sebagai hukum yang berlaku bagi golongan Indonesia asli di samping berlakunya hukum perdata Barat bagi golongan Eropa dan yang dipersamakan yang sudah terkodifikasi di dalam Kitab Undangundang Hukum Perdata (B.W.). Pasca kolonial, atau masa kemerdekaan, pendapat mazhab sejarah-lah yang menentang sistem kodifikasi hukum adat tidak dianut, sehingga hukum adat dapat bertahan hingga kini. Meskipun dalam perkembangannya berlaku sistem kodifikasi, hal ini tidak berarti mematikan hukum adat karena dianutnya sistem terbuka atau asas kebebasan berkontrak di dalam hukum perjanjian. Zulfa Djoko Basuki, "Mazhab Sejarah dan Pengaruhnya terhadap Pembentukan Hukum Nasional", dalam Filsafat Hukum: Mazhab dan Refleksinya, ed. Lili Rasjidi dan B. Arief Sidharta (Bandung: Remaja Rosdakarya, cetakan kedua, 1994), hlm. 31 dan 44.

6 Hal ini bisa terjadi barangkali karena dua alasan. Pertama, karya yang membahas Savigny dan pemikirannya saat ini jauh lebih mudah didapat ketimbang karya Savigny sendiri. Banyak di antaranya bahkan dapat diakses secara terbuka (open access). Kedua, artikel yang khusus membahas seorang tokoh dan pemikirannya biasanya akan secara runtut menguraikan latar belakang dan menerangkan inti pemikiran Sang Tokoh, dibanding harus membaca karyanya yang harus mengidentifikasi, memahami, dan memetakannya lagi. Karena alasan yang kedua ini, maka artikel ini juga tidak lepas dan bebas dari pengaruh identifikasi, pemahaman, dan pemetaan artikel-artikel berpengaruh sebelumnya yang membahas pemikiran Sang 
Meski demikian, adanya bahasan dalam artikel ini tentang urgensi dan relevansi pemikiran Sang Tokoh terhadap dinamika sosial saat ini, barangkali bisa membedakannya dengan artikel-artikel terdahulu. Sebagai demikian, artikel ini setelah bagian ini akan memaparkan riwayat hidup dan karya Sang Tokoh, dan kemudian dilanjutkan pada uraian latar belakang dan pembahasan inti pemikirannya. Bagian berikutnya akan mendiskusikan urgensi dan relevansi pemikiran Sang Tokoh dalam perkembangan dan pembangunan hukum saat ini. Bahasan yang terakhir ini menunjukkan bahwa kita perlu untuk memahami dan dalam beberapa hal meresepsi kearifan masa lampau yang sudah teruji dalam membangun dan mengembangkan sendisendi kehidupan masyarakat pada saat ini termasuk dalam bidang hukumnya.

\section{B. Riwayat Hidup dan Karya Savigny}

Friedrich Carl von Savigny ${ }^{7}$ lahir di Frankfurt, Main pada 21 Februari 1779. Bapaknya Christian Karl Ludwig vo Savigny hidup pada 17261791, dan ibunya Philippine Henriette Groos hidup pada 1743-1792. Bapaknya merupakan seorang ahli hukum, yang meninggal ketika Savigny berusia 12 tahun. Setahun kemudian ibunya juga meninggal, dan menjadilah Savigny yatim-piatu tanpa memiliki saudara, karena saudara-saudaranya meninggal muda bahkan sebelum orang tuanya. Setelah itu Savigny diasuh oleh M. de Neurath, seorang penilai Imperial Chamber, yang merupakan teman bapaknya. ${ }^{8}$

Pada usia 15 tahun, Savigny bersama anak Neurath diikutkan kursus ilmu hukum, hukum alam, hukum internasional, hukum

Tokoh, sebagaimana yang menjadi referensi penulisan ini.

7 Artikel ini secara lengkap menuliskan nama tokoh ini dengan Friedrich Carl von Savigny, sebagaimana penulisan dalam bukunya System of the Modern Roman Law versi bahasa Inggris. Namun begitu, ejaan dua nama pertamanya dalam banyak literatur yang dirujuk pada artikel ini sebenarnya ditulis secara berbeda-beda. Pada nama pertama, ejaan lainnya yang dijumpai adalah Friedrick dan Frederick, sedangkan ejaan lainnya pada nama kedua yang ditemui adalah Karl dan Charles.

8 J.E.G. de Montmorency, "Friedrich Carl von Savigny", Journal of the Society of Comparative Legislation, 11, 1 (1910), hlm. 32-33; The Young Savigny, "Friedrich Carl von Savigny in the Years 1779 to 1810 ". 
Romawi, hukum Jerman, dan sebagainya. Pada usia 17 tahun (1795), ia belajar hukum di Marburg University. Pada Oktober 1796, ia belajar sejarah di University of Gottiengen, namun pada musim semi tahun berikutnya kembali ke Marburg. Antara 1799-1800, Savigny mengunjungi dan belajar di berbagai universitas, termasuk Leipzig dan Jena. Tahun 1800, Savigny mendapatkan gelar doktor di Marburg, dengan disertasi De concursu Delictorum formali (Vermischte Schriften, iv. 74). ${ }^{9}$ Pada tahun itu juga Savigny diterima sebagai pengajar di Marburg untuk matakuliah hukum pidana, di samping sebagai tambahannya (additional or extraordinary professor) ada matakuliah 10 buku Pandects Ulpian, hukum suksesi, kewajiban, metodologi hukum, dan sejarah hukum Romawi. ${ }^{10}$

Sesaat sebelum menikah dengan Fraulein Kunigunde Brentano pada 1804, Savigny berhenti dari University of Marburg dan menolak tawaran dari Universitas Heidelberg dan Greifswald, untuk melanjutkan penelitian di perpustakaan-perpustakaan terkenal di Heidelberg, Stutgart, Tubingen, Strasbourg, dan Paris. Tahun 1808, ia mengambil pekerjaan di University of Landshut selama 1,5 tahun. Tahun 1810 Savigny menerima tawaran memimpin Fakultas Hukum di University of Berlin hingga 1842. Di sini ia mengajar the Pandects pada semester musim dingin dan the Institutes pada semester musim panas. Ia juga mengajar Ulpian, Gaius, dan the Prussian Landrecht. ${ }^{11}$ Kampus ini pula yang dalam perkembangannya dikenali memberi dampak besar dalam studi hukum, tidak hanya Jerman tapi juga Eropa. ${ }^{12}$

Pada 1811 Savigny terpilih sebagai anggota Akademi Berlin, dan

9 Montmorency, "Friedrich Carl von Savigny”, hlm. 33.

10 Montmorency, "Friedrich Carl von Savigny", hlm. 33-34.

11 Montmorency, "Friedrich Carl von Savigny", hlm. 40-41.

12 Hermann Klenner mengatakan, tidak ada universitas di Jerman pada abad 19 yang dapat dibandingkan dengan Berlin dalam soal studi hukum. Bahkan tidak pula kota di Eropa pada masa itu yang memiliki ilmuwan hukum yang besar seperti di Berlin, antara lain Eichorn, Fichte, Gans, Gentz, Gierke, Greist, Grimm, Hegel, Jhering, Kirchmann, Klein, Lassale, Marx, Mommsen, Mullert, Puchta, Schopenhauer, Stahl, Svarez, dan tentu saja Savigny. Klenner, "Savigny's Research Program of the Historical hlm. 69. 
karena itu ia berkesempatan membaca kontrak Romawi yang tertulis, hukum Voconian, hak-hak kreditur menurut hukum Romawi kuno, dan sejarah bangsawan pada Eropa modern. ${ }^{13}$ Pada 1819, Savigny ditunjuk sebagai konselor pengadilan banding dan kasasi di Berlin. ${ }^{14}$ Tahun 1842, Savigny mengundurkan diri dari pimpinan University of Berlin dan menjadi Menteri Keadilan sampai 1848. Savigny meninggal pada 25 Oktober 1861, ketika usianya sudah 83 tahun. ${ }^{15}$

Selama hidupnya, Savigny menghasilkan banyak karya dan sebagian besar berpengaruh bahkan hingga sekarang. Di antara karya tersebut adalah, Das Recht des Besitzes (the Right of Possession), yang dihasilkan pada 1803. Karya ini terdiri dari enam buku: gagasan kepemilikan; akuisisi kepemilikan; kerugian; larangan sebagai solusi untuk melindungi kepemilikan; kepemilikan dalam kaitannya dengan hak-hak hukum; dan doktrin kepemilikan oleh Savigny. ${ }^{16}$ Pada 1814, Savigny menghasilkan karya De la Vocation de notre siecle pour la legislation et la science $d u$ droit (The Vocation of our Age for Legislation and Jusrisprudence), yang mengkritisi usulan Kode Sipil yang tidak mengadopsi prinsip-prinsip hukum Romawi. ${ }^{17}$ Tahun 1839, ia menulis The System of the Modern Roman Law dalam delapan volume: lima dipublikasikan pada 1840 dan tiga lagi pada $1847 .{ }^{18}$

\section{Hukum sebagai Manifestasi Jiwa Bangsa: Asal Muasal dan Bentuknya}

Beberapa pertanyaan yang perlu diulas terkait pemikiran Savigny tentang hukum adalah: apa sebenarnya yang dimaksud dengan hukum dan volksgeist oleh Savigny dan apa keterkaitan antar keduanya; apa yang melatarbelakangi pemikiran bahwa hukum harus merupakan manifestasi dari volksgeist; dan bagaimana bentuk hukum yang merupakan manifestasi volksgeist itu. Bagian ini mencoba

13 Montmorency, "Friedrich Carl von Savigny”, hlm. 41.

14 Montmorency, "Friedrich Carl von Savigny”, hlm. 41.

15 Montmorency, "Friedrich Carl von Savigny”, hlm. 51.

16 Montmorency, "Friedrich Carl von Savigny”, hlm. 38.

17 Montmorency, "Friedrich Carl von Savigny”, hlm. 41; 43.

18 Montmorency, "Friedrich Carl von Savigny”, hlm. 48. 
mengulasnya.

Untuk memahami latar belakang pemikiran hukum dan volksgeist dari Savigny, perlu disebutkan kembali karya-karya penting dari Savigny dan kapan ia dihasilkan. Setidaknya ada tiga karya penting dari Savigny, ${ }^{19}$ yaitu pertama, Das Recht des Besitzes yang diterjemahkan ke bahasa Inggris menjadi The Right of Possession; kedua, De la Vocation de notre siecle pour la legislation et la science du droit, yang diterjemahkan menjadi The Vocation of our Age for Legislation and Jusrisprudence; dan ketiga, The System of the Modern Roman Law. Karya yang disebut pertama dihasilkan pada 1803, saat usianya masih belum genap 24 tahun, sedangkan yang kedua pada 1814, dan yang ketiga 1839. Dari perspektif sejarah, selisih rentang tahun ini menjadi penting untuk melihat konsistensi sekaligus perkembangan pemikiran Sang Tokoh.

Sebelum mengungkap pandangan Savigny tentang hukum, perlu disampaikan bahwa ketika karya-karyanya dihasilkan, Jerman sebenarnya sedang mencari bentuk sebagai sebuah negara yang definitif. Sebagai sebuah negara, Jerman sebetulnya tidak benar-benar ada sampai abad ke 19. Walau secara formal memiliki kaisar, Jerman tidak punya sebagian atribut penting untuk disebut negara berdaulat. Jerman terdiri dari ratusan kerajaan dan daerah kekuasaan pangeran yang merdeka, sebagian di antaranya masih saling berperang. Kekaisaran yang lemah ini dibubarkan pada 1806, dan Jerman baru didirikan kembali sebagai sebuah negara pada $1871 .^{20}$

Dengan keadaan seperti itu, tidak mengherankan jika Jerman juga tidak punya sistem hukum sendiri sampai abad ke 19. Sebagian besar negara-kecil Jerman memberlakukan hukum adat lokal sejak Abad Pertengahan. Sebagian dari hukum lokal ini tertulis dalam karya-karya kuno dari abad ke 13, dan secara mengejutkan dilengkapi dengan hukum Romawi, ${ }^{21}$ yang menunjukkan resepsi hukum

19 Penyebutan karya penting ini didasarkan pada pembacaan berbagai referensi tentang Savigny yang pada umumnya merujuk ke tiga karya tersebut.

20 Michael Bogdan, Pengantar Perbandingan Sistem Hukum, terj. Derta Sri Widowatie (Bandung: Nusa Media, 2010), hlm. 241.

21 Bogdan, Pengantar Perbandingan Sistem Hukum, hlm. 241-242. 
Romawi di wilayah Jerman.

Penerimaan atau resepsi secara meluas hukum Romawi (Corpus iuris civilis) di Jerman ini sesungguhnya bersifat ideologis dan psikologis, yaitu ketika Kekaisaran Jerman yang ada antara 9621806 merepresentasikan diri sebagai penerus Kekaisaran Romawi. Hukum Romawi lalu dipelajari pada universitas-universitas di Jerman dan digunakan sebagai sumber hukum tambahan manakala hukum lokal tidak mengatur dan memberikan solusi. Maka, membicarakan hukum yang berlaku untuk seluruh Kekaisaran pada saat itu sama halnya membicarakan hukum Romawi, meskipun juga harus dikatakan sebagai hukum Romawi yang mengandung unsur-unsur Jerman. $^{22}$

Latar keadaan demikian tentu juga memengaruhi pemikiran Savigny tentang hukum, dalam artian merespons situasi pada saat itu. Sebagaimana tadi dikatakan, sampai abad ke 19, Jerman sebenarnya tidak mepunyai sistem hukum sendiri. Kode Sipil yang terpadu untuk wilayah Jerman belumlah ada. Anton F.L. Thibaut, seorang Profesor hukum Romawi di Heidelberg, kemudian menulis buku yang mengusulkan agar kodifikasi hukum diadopsi di Jerman. Thibaut mengajukan agar satu undang-undang tunggal yang terpadu untuk negara-negara Jerman dirancang oleh Komite Antar Negara Bagian. Dengan pengaruh hukum kodrat, Thibaut berasumsi bahwa komite ahli hukum dan praktisi seperti itu akan dapat menyusun undangundang yang sesuai, dan, lebih jauh, secara dogmatis menyatakan bahwa kodifikasi dapat merevolusi sistem hukum dengan segera. ${ }^{23}$

Proposal Thibaut ini diajukan setelah perang Napoleon, dan karenanya terkait dengan gejolak nasionalisme baru yang pada saat itu sedang bangkit di Jerman ${ }^{24}$ dan reaksi yang berkembang

22 Bogdan, Pengantar Perbandingan Sistem Hukum, hlm. 242.

23 Luis Kutner, "Legal Philosophers: Savigny: German Lawgiver”, Marquette Law Review, 55, 2 (1972), hlm. 282.

24 Gejolak nasionalisme di Jerman ini terjadi antara lain karena pengaruh Revolusi Perancis, yang memang memaksa perubahan di Eropa, menghancurkan Kekaisaran Romawi Suci, dan mengubah Jerman menjadi laboratorium konstitusional (pada 1847, tinggal empat dari 39 negara anggota konfederasi Jerman yang belum memiliki konstitusi). Karena 
terhadap Romawi atau hukum asing lainnya. Gagasan nasionalis yang baru menolak adopsi kode Perancis untuk Jerman, dengan alasan ketidaksamaan situasi Jerman dengan Perancis. Demikian juga, hukum Romawi, yang diajarkan pada universitas-universitas dan telah mendominasi administrasi dan ajudikasi hukum Jerman, juga dikecam oleh kaum nasionalis sebagai "hukum asing" (alien law). Bagi mereka, bagaimana mungkin sebuah sistem hukum yang diciptakan oleh orang Romawi kuno untuk kebutuhan mereka antara abad ke-5 SM. dan abad ke-6 M berlaku pula untuk kebutuhan orangorang Jerman pada abad ke-19? Oleh karena itu, diusulkan bahwa "hukum alien" digantikan oleh sistem hukum asli Jerman. ${ }^{25}$

Merespons usulan Thibaut tersebut, Savigny lalu merefleksikan hukum dengan mengajukan pertanyaan: bagaimana sebenarnya hukum telah berkembang pada bangsa-bangsa manusia yang beradab. Pertanyaan ini sesungguhnya memersoalkan pusat hukum dan hubungannya dengan konteks sosial. Dalam identifikasi Savigny, pada masa-masa paling awal di mana sejarah masyarakat yang otentik masih terlihat, hukum telah dijumpai pada saat itu, seperti juga halnya bahasa, tata krama, dan konstitusi mereka. Fenomenafenomena ini, bahasa, tata krama, hukum, konstitusi, tidak memiliki keberadaan yang terpisah. Apa yang mengikat berbagai fenomena itu menjadi satu kesatuan adalah keyakinan umum orang-orang atau rakyat (the common conviction of the people), yaitu kesadaran yang sama dari kebutuhan batin (the kindred consciousness of an inward necessity). Karena itu hukum, seperti halnya bahasa, berada dalam kesadaran rakyat (the consciousness of people). ${ }^{26}$

Dalam pandangan Savigny, semua hukum pada awalnya berkembang dari adat dan kebiasaan, dan baru selanjutnya oleh yurisprudensi. Jika ditanyakan tentang subjek di mana dan untuk

itu, David Blackbourn menyebut Revolusi Perancis bersifat transformatif. David Blackbourn, "Germany and the Birth of the Modern World, 17801820”, Bulletin of the German Historical Institute, 51 (2012), hlm. 14.

25 Kutner, "Legal Philosophers: Savigny”, hlm. 282-283.

26 Frederick Charles von Savigny, Of The Vocation of Our Age for Legislation, terj. Abraham Hayward (London: Littlewood \& Co. Old Bailey, tanpa tahun), hlm. 24-25. 
mana hukum ada, maka ditemukan orang-orang yang menjadi subjeknya. Mereka bukanlah orang-orang istimewa dengan kewenangan-kewenangan yang khusus dalam soal hukum. Hukum yang ada tidaklah dibentuk. Semangat orang-orang yang hidup dan bekerjasama-lah yang melahirkan hukum. Dalam kesadaran umum suatu masyarakat itulah berlaku dan ditemukan hukum, dan karenanya harus disebut hukum rakyat. Hukum dengan begitu berkembang melalui kekuatan internal yang beroperasi secara diam-diam (internal silently-operating powers), bukan oleh kehendak sewenang-wenang dari pembentuk hukum. ${ }^{27}$

Dari uraian ini terlihat bahwa padangan Savigny tentang hukum lebih untuk merespons usulan kontroversial terkait kodifikasi di Jerman. Bagi Savigny, hukum harus dipahami sebagai bagian dari aspek kehidupan sosial. Hukum adalah bagian dari kompleks pengalaman dan karakter masyarakat. Savigny menolak asumsi bahwa hukum merupakan fenomena yang mandiri atau otonom dan berlaku universal. Mengasumsikan hukum itu "universal", disebutnya keliru dan hanya menjadi ilusi. Savigny mendorong supaya hukum, sesuai sejarah perkembangannya, menyatu dengan kehidupan sosial masyarakat seperti halnya bahasa, tata krama, dan lain-lainnya. ${ }^{28}$ Proposal kodifikasi oleh Thibaut dikhawatirkan mendorong terjadinya transformasi radikal dalam hubungan sosial oleh kekuatan demokrasi. Savigny mengutuk Pencerahan, karena justru membuat kepercayaan politik dan agama di masyarakat menjadi goyah. ${ }^{29}$

Dipengaruhi oleh gurunya di Gottingen, Profesor Hugo, Savigny menegaskan bahwa hubungan unik antara hukum dan kehidupan setiap masyarakat tertentu merusak tesis hukum kodrat dari sudut pandang sejarah dan pengalaman manusia. Ia menentang gagasan hukum kodrat atau alam tentang hukum yang universal,

27 Savigny, Of The Vocation of Our Age for Legislation, hlm. 29-30; Friedrich Carl von Savigny, System of the Modern Roman Law Vol. 1, terj. William Holloway (Madras: J. Hingginbotham Publisher, 1867), hlm. 12-13.

28 Kutner, "Legal Philosophers: Savigny”, hlm. 283.

29 Karl A. Mollnau, "The Contributions of Savigny to the Theory of Legislation”, The American Journal of Comparative Law, 37, 1 (1989), hlm. 85 . 
sebab, membuktikan pengaruh Hugo, hukum harus mencerminkan kebutuhan dan karakter unik masyarakat setiap bangsa. DisiniSavigny membalikkan argumen yang sebelumnya dikutip untuk kodifikasi di Jerman untuk kemudian digunakan sebagai keberatannya, bahwa pemberlakuan kode semacam itu, yang meniru karya Napoleon di Perancis dan negara-negara lain yang ditundukkannya, hanya akan menjadi impor yang gegabah (a reckless importation). ${ }^{30}$ Dalam diskursus ilmu hukum sekarang, pemberlakuan kode semacam itu, yang memindahkan (impor) hukum dari satu tempat ke tempat lain, disebut sebagai "transplantasi hukum"; suatu kosakata dalam diskursus ilmu hukum yang diperkenalkan Alan Watson. ${ }^{31}$

Dalam penelusuran Savigny, hukum pada tahap perkembangannya yang paling awal diekspresikan secara spontan dari kebiasaan dan tradisi adat. Bahwa satu-satunya sumber sejati semua hukum datang langsung dari adat, menurut Savigny, adalah bukti keberadaannya. Dengan rasa hormatnya yang tinggi pada masa lalu bangsanya sendiri, Savigny mengatakan, keberagaman bentukbentuk hukum tidak berevolusi berdasarkan refleksi alamiah yang disengaja atau pertimbangan utilitas yang beralasan, melainkan muncul dari keyakinan umum rakyat, suatu perasaan yang sama seperti kebutuhan batin. ${ }^{32}$

Bagi Savigny, hukum itu ada terlepas dari negara. Ia adalah ciptaan, bukan berasal darialam atau Tuhan, melainkan dari kesadaran nasional (the national consciousness). Dengan demikian, supremasi hukum secara misterius dilahirkan dari jiwa rakyat atau bangsa (spirit of the people, atau volksgeist) yang sudah ada sebelumnya. Karena berasal dari jiwa unik masyarakat (the unique spirit of the people), maka hukum tidak dibuat, dan volksgeist menjadi dasar untuk mempelajari

30 Kutner, "Legal Philosophers: Savigny”, hlm. 283-284.

31 Menurut Alan Watson (Legal Transplants: An Approach to Comparative Law [Athens, University of Georgia Press, edisi kedua, 1993], hlm. 21), legal transplant adalah "the moving of a rule or a system of law from one country to another, or from one people to another", yang berarti pemindahan aturan atau sistem hukum dari satu negara ke negara lain, atau dari satu orang ke orang lain.

32 Kutner, "Legal Philosophers: Savigny”, hlm. 285-286. 
semua manifestasinya. ${ }^{33}$ Karena hukum tidak dibuat, maka legislasi dalam pandangan Savigny menjadi tidak penting, kecuali memiliki sifat deklaratif. ${ }^{34}$

Pandangan Savigny yang demikian itu menegaskan bahwa hukum "tidak ada dalam dirinya sendiri", sebab esensinya adalah "kehidupan manusia" yang dilihat dari aspek tertentu. ${ }^{35}$ Hukum bukan produk yang dibentuk dengan alasan tertentu dan lalu ditetapkan dalam undang-undang. Hukum bahkan bukan sesuatu yang ada, tetapi suatu kesadaran yang hidup dan berubah yang selamanya berada dalam proses menjadi. Dalam arti penting, hukum, sebagaimana dikatakan Roger Berkowitz, oleh karenanya dapat dikatakan tidak ada. ${ }^{36}$

Kalaupun ada, hukum pada awalnya berada dalam kesatuannya dengan bahasa, moral, dan ketertiban sebagai emanasi atau pancaran kepercayaan rakyat. Ini sebabnya, hubungan organik antara manusia dan hukum ada dalam konsep budaya yang lebih universal, yang dibangun berdasarkan bahasa, moral, dan ketertiban. Hukum sebagai bagian dari budaya digambarkan sebagai fenomena kesatuan; dan hanya dengan itu bisa dipahami. Dengan begitu, hukum merupakan bagian saja di antara aspek integratif budaya, ${ }^{37}$ dan karenanya juga dapat dikatakan, sebagaimana Augusto Zimmermann, hukum merupakan produk konvensi budaya. ${ }^{38}$

Sampai di sini cukup jelas bahwa pandangan Savigny tentang hukum lebih merupakan refleksinya dalam merespons usulan kodifikasi untuk seluruh wilayah Jerman. Sebagaimana diketahui,

33 Kutner, "Legal Philosophers: Savigny”, hlm. 284.

34 Carl Joachim Friedrich, Filsafat Hukum: Perspektif Historis, terj. Raisul Muttaqien (Bandung: Nusa Media, cetakan keempat, 2014), hlm. 175.

35 Klenner, "Savigny's Research Program of the Historical”, hlm. 69.

36 Roger Berkowitz, "From Justice to Justification: An Alternative Genealogy of Positive Law”, UC Irvine Law Review, 1, 3 (2011), hlm. 620.

37 Gerhard Dilcher, "The Germanist and the Historical School of Law: German Legal Science between Romanticism, Realism, and Rationalism”, Zitiervorschlag: Rechtsgeschichte - Legal History Rg 24 (2016), hlm. 29-30.

38 Augusto Zimmermann, “The 'Darwin’ of German Legal Theory-Carl von Savigny and the German School of Historical Law”, Journal of Creation, 27, 2 (2013), hlm. 110. 
Jerman saat itu belum merupakan negara yang definitif dan karenanya belum memiliki sistem hukum yang menyeluruh dalam artian menasional. Hukum yang ada masih terpisah-pisah pada Negara Bagian dan berlaku secara lokal. Savigny lalu menolak usulan hukum yang berlaku secara universal, disebabkan dalam perenungannya hukum itu tumbuh secara alamiah di masyarakat, tidak dibuat secara sengaja, misalnya oleh kekuatan politik tertentu. Hukum menjadi bagian dari kehidupan sosial masyarakat yang dapat dilihat dalam wujud perilaku masyarakat, seperti juga halnya bahasa dan tata krama. Ia menjadi satu kesatuan, yang berasal dari kesadaran masyarakat dan jiwa rakyat atau bangsa (spirit of the people, volksgeist).

Salah satu yang menarik dari paparan barusan adalah tentang istilah volksgeist. Sekalipun dari segi makna relatif jelas, ialah kesadaran masyarakat, jiwa rakyat, atau jiwa bangsa, artikel ini tidak berhasil membuktikan istilah tersebut telah digunakan Savigny. Dalam dua karya Savigny yang dirujuk dalam artikel ini, Of The Vocation of Our Age for Legislation dan System of the Modern Roman Law Vol. 1, istilah ini tidak-lah dijumpai! Tapi hal ini bukan lalu berarti Savigny tidak menggunakannya. Sebab, kedua karya tersebut dalam penulisan artikel ini dijumpai dalam versi terjemahan bahasa Inggris, dari edisi aslinya dalam bahasa Jerman. Dalam versi bahasa Inggris, dengan maksud jiwa rakyat atau bangsa, istilah yang ditemukan adalah spirit of the people. Namun demikian, ketidakjumpaan istilah volksgeist juga ditemukan dalam artikel yang relatif mula-mula menulis tentang Savigny dan pemikirannya, yang dalam artikel ini merujuk pada karya Montmorency, yang ditulis pada 1910. Karena itu, penting untuk menelusuri istilah volksgeist ini, dan apakah tepat menyematkannya dan apalagi mengidentikkannya sebagai bagian dari pemikiran Savigny.

Di antara yang membahas istilah volksgeist ialah artikel yang ditulis Mathias Reimann dan Robert E. Rodes. Reimann menulis, "It was therefore an expression of what Savigny later called the 'Volksgeist', the spirit of the people", ${ }^{39}$ sedangkan menurut Rodes, "In later works,

39 Mathias Reimann, "Nineteenth Century German Legal Science”, Boston College Law Review, 31, 4 (1990), hlm. 853. 
Savigny was to use the term Volksgeist, spirit of the people, to designate what he regarded as the source of law". ${ }^{40}$ Dalam menulis kalimat tersebut, baik Reimann maupun Rodes merujuk pada System des heutigen Romischen Rechts, Vol. 1, yang merupakan versi asli dari System of the Modern Roman Law Vol. 1. Rodes melanjutkan, kata Jerman volksgeist (dengan huruf ' $\mathrm{s}$ ' di antara ' $\mathrm{k}$ ' dan ' $\mathrm{g}$ ') lebih menggugah ketimbang terjemahannya, dan karenanya istilah ini digunakannya dalam artikel yang ditulisnya. ${ }^{41}$ Oleh kedua penulis ini disebut, istilah volksgeist sendiri bukalanlah dari Savigny. Istilah ini digunakan pertama kali dalam filsafat oleh G.W.F. Hegel pada 1822-1823, dan dalam kaitannya dengan hukum, yang pertama menggunakannya adalah Puchta pada $1828 .{ }^{42}$

Volksgeist sendiri memiliki arti yang sangat spesifik. Volk dalam konteks ini bukan sosial atau empiris, melainkan konsep budaya; dan geist, bukan seperti Weltgeist-nya Hegel yaitu entitas intelektual yang sangat abstrak, melainkan sesuatu yang konkret, yaitu karakteristik budaya suatu masyarakat. Karena itu, volksgeist berarti karakter suatu bangsa sebagai budaya, dan hukum bagi Savigny adalah bagian dari karakter ini (esensi hukum adalah kehidupan manusia itu sendiri, dilihat dari perspektif tertentu). Di sini Savigny mendalilkan secara modern, bahwa esensi volksgeit bukan filsafat atau alasan, tetapi ekspresi karakteristik budaya. Oleh karena itu, ia merupakan fenomena historis, dan bukan metafisik. ${ }^{43}$ Atas dasar alasan inilah artikel ini, sebagaimana tersua dalam judul, lebih cenderung menggunakan "jiwa bangsa" sebagai padanan volksgeist atau spirit of the people dalam bahasa Indonesia. ${ }^{44}$

40 Robert E. Rodes, "On the Historical School of Jurisprudence”, The American Journal of Jurisprudence, 49 (2004), hlm. 166.

41 Rodes, "On the Historical School of Jurisprudence", hlm. 166.

42 Rodes, "On the Historical School of Jurisprudence", hlm. 166.

43 Reimann, "Nineteenth Century German Legal Science”, hlm. 853.

44 Dalam Kamus Besar Bahasa Indonesia, rakyat diartikan antara lain sebagai "penduduk suatu negara; orang kebanyakan; orang biasa"; sedangkan bangsa diartikan antara lain sebagai "kelompok masyarakat yang bersamaan asal keturunan, adat, bahasa, dan sejarahnya, serta berpemerintahan sendiri; kumpulan manusia yang biasanya terikat karena kesatuan bahasa dan kebudayaan dalam arti umum, dan menempati wilayah tertentu di 
Dari perspektif waktu, pandangan Savigny yang demikian itu lebih terlihat pada saat ia menulis The Vocation of our Age for Legislation and Jusrisprudence pada 1814. Namun, dalam karya berikutnya, The System of the Modern Roman Law, yang ditulis 1840, pandangan semacam itu dalam beberapa hal telah mengalami pergeseran. Dalam pembacaan John E. Toews, beberapa yang berubah itu adalah, bahwa Savigny mengakui adanya peran ahli hukum dan kesadarannya dalam perkembangan hukum belakangan. Jika pada fase sebelumnya lebih terlihat pandangan tentang hukum yang muncul dan berkembang bersama dengan kesadaran rakyat sehingga hukum terlihat dalam "hukum rakyat", maka belakangan ini hukum dilihatnya telah mengartikulasi dalam bahasa dan prinsip-prinsip ilmiah. Fungsi rakyat sebagai subjek hukum terpadu yang kreatif dilihatnya secara bertahap berpindah ke tangan para ahli hukum dan kalangan terpelajar, sehingga kesadaran hukum bersama sebagai totalitas organik kini diartikulasikan dalam pemahaman dan kerjakerja yang terorganisasi dan sistematis. Karena itu, jika sebelumnya hukum (sepenuhnya) hidup dalam kesadaran rakyat, maka sekarang juga berada dalam kesadaran para ahli hukum. Pergeseran ini memang tidak mengubah sepenuhnya pandangan Savigny tentang

muka bumi” (Badan Pengembangan dan Pembinaan Bahasa Kementerian Pendidikan dan Kebudayaan Republik Indonesia, Kamus Besar Bahasa Indonesia, https://kbbi.kemdikbud.go.id, diakses 10/4/2020). Dalam literatur politik, bangsa antara lain dimaknai sebagai "suatu entitas primordial yang merupakan bawaan yang melekat dalam nature dan sejarah manusia sebagai sebuah kelompok" (Cornelis Lay, "Nasionalisme dan Negara Bangsa”, Jurnal Ilmu Sosial dan Ilmu Politik, 10, 2 [2006], hlm. 169). Dalam makna tersebut, kata Lay, secara obyektif suatu bangsa dapat diidentifikasi lewat perbedaan-perbedaannya dengan bangsa lain dalam hal cara pandang, keterikatan dengan tanah air, dan perjuangan-perjuangan untuk mendapatkan otonomi politik. Dengan merujuk makna bangsa yang demikian, yang menunjukkan adanya kesamaan-kesamaan di dalam kelompok yang disebut bangsa sehingga bisa dibedakan dengan bangsa lain, maka jiwa bangsa dipilih dalam artikel ini untuk digunakan sebagai padanan spirit of the people, sebab dalam spirit of the people atau istilah aslinya volksgeist, sebagaimana diungkap dalam artikel ini, terkandung di dalamnya karakter suatu bangsa sebagai budaya dan kesadaran nasional (the national consciousness), yang memang akan membedakan volksgeist suatu kelompok masyarakat (bangsa) dengan kelompok (bangsa) lain. 
perkembangan hukum, melainkan justru mengingatkan bahwa dalam perkembangan masyarakat modern dibutuhkan kesadaran sejarah dari para aktornya. Tanpa pemahaman dan kesadaran yang demikian itu dari ahli hukum, maka tidak mungkin berbagai kompleksitas budaya dalam masyarakat modern akan terkoneksi dengan bahanbahan warisan sejarah yang terakumulasi dan membentuk ingatan kolektif masyarakat dan para ahli hukum. Padahal, konektivitas itu penting agar terjalin kontinuitas antara masa lalu, sekarang, dan masa depan. ${ }^{45}$

Pandangan Savigny ini menunjukkan sikapnya yang kini menganggap penting peran negara. Savigny memang bersikeras bahwa negara bukanlah pencipta komunitas budaya; kekuatannya tetap "eksternal", dalam wilayah yang kasat mata, dan ia berasal "pada manusia, melalui manusia dan untuk manusia". Namun, pada saat yang sama, negara dipandang penting untuk mengaktualisasikan komunitas kehendak yang tak kasat mata di dunia dan mencegah disintegrasi komunitas itu ke dalam kehendak egois. Karena itu perlu adanya organisasi yang memiliki kesadaran dan kekuatan untuk mempertahankan organisme masyarakat, dalam hal ini adalah negara. ${ }^{46}$

Dalam kaitannya dengan hukum, maka negara menjadi sumber legislasi yang dipandang penting dalam mewujudkan dan mengarahkan evolusi historis organisme masyarakat. Negara dengan kekuatan legislatifnya bukan (lagi) dianggap sebagai ancaman bagi kekuatan spontan dan jiwa bangsa, melainkan malah menjadi representasi yang otentik (authentic representative) dari semangat itu. Negara dalam hal ini memainkan dua peranan penting sekaligus, yaitu mengadaptasi dan menengahi kontradiksi antara struktur "lama" yang diwarisi dan pengalaman-pengalaman "baru". Penciptaan dan adaptasi hukum melalui undang-undang dianggap memiliki "otonomi" dan "martabat" yang sama dengan kekuatan diam-diam

45 John E. Toews, "The Immanent Genesis and Transendent Goal of Law: Savigny, Stahl, and the Ideology of the Christian German State", The American Journal of Comparative Law, 37, 1 (1989), hlm. 146.

46 Toews, “The Immanent Genesis and Transendent Goal of Law”, hlm. 148. 
dan bertahap dari volksgeist. Dalam adaptasi ini, ilmu hukum (sejarah) memberi "materi" bagi kekuatan legislasi dengan memberinya bentuk. Di sisi yang lebih praksis, ilmu hukum (sejarah) menjalankan fungsi mediasi antara tradisi komunal yang masih penting dalam kesadaran masyarakat yang terus berkembang (betapapun terkubur oleh kesalahan dan penyimpangan yang mungkin terjadi) dan pendisiplinan, pengorganisasian, dan representasi kesadaran itu oleh negara. ${ }^{47}$

Pada akhirnya, dan ini tampaknya tidak terbaca yang lainnya, pemikiran Savigny yang berperspektif historis ini dilihat oleh John E. Toews sebagai pemikiran yang tidak sepenuhnya berada dalam wilayah imanen, melainkan juga transenden. ${ }^{48}$ Pemikiran Savigny lebih terbaca imanen karena memang lebih menekankan hukum sebagai bagian dari sejarah bangsa, yang muncul, berubah, dan berakhirnya pun turut mengikuti sejarah bangsa. Namun Toews melihat juga aspek transendentalnya, yaitu tatkala Savigny memberi penekan pada prinsip-prinsip etika yang didasarkan pada agama, bahwa hukum bukan semata merupakan pencerminan dari budaya suatu masyarakat dengan orang-orang yang penuh kebebasan, tetapi juga dalam hal tujuan ke mana kebebasan ini harus diarahkan. Dalam soal tujuan ini, tugas hukum yang lebih universal disebutnya dapat direduksi pada penentuan etis dari sifat manusia sebagaimana pandangan hidup dalam agama. Karena itu, kepercayaan agama diyakininya menjadi dasar dari etika sosial. ${ }^{49}$

Dari perspektif perkembangan hukum, maka hukum yang

47 Toews, "The Immanent Genesis and Transendent Goal of Law”, hlm. 148.

48 Sesuatu disebut imanen berarti menunjukkan berada dalam wilayah "di sini" dan waktu "sekarang", yang berarti penuh dengan kesementaraan. Sebaliknya, sesuatu dikatakan transenden karena berada dalam wilayah "di sana, langit" dan waktu "kapan saja", yang berarti mengarah pada ketidaksementaraan.

49 Toews, "The Immanent Genesis and Transendent Goal of Law”, hlm. 149150. Bagi Savigny, hal ini menjadi jelas bahwa kerja spontan kesadaran budaya kolektif bukanlah jaminan yang memadai untuk pemenuhan tujuan sosial atau moral umat manusia. Karenanya, negara dan agama menjadi unsur tambahan yang diperlukan, dengan kekuatan pendisiplinan dan otoritas transenden, untuk membimbing etika umat manusia. 
sebelumnya disebut berevolusi secara spontan dari subjek nasional kini bergerak ke arah peningkatan kehendak etis. Di sini berarti dipandang perlu mencari landasan ekstra-historis, yaitu pada norma-norma etis yang sifatnya sangat transendental, untuk selanjutnya secara kritis diterapkan pada hubungan kehidupan aktual dari budaya masyarakat tertentu. Makna dan tujuan hubungan manusia tidak ditafsirkan dari hubungan itu sendiri, tetapi juga melalui hubungannya dengan beberapa "yang lain" yang transenden. Lingkup hubungan manusia secara horisontal dan ruang yang diatur oleh hukum sipil, akan mencapai makna dan landasannya hanya dalam konteks hubungan vertikal ke ranah di luar sejarah dan di luar manusia. ${ }^{50}$

Pemikiran Savigny yang menelusuri perkembangan hukum ini, yang dalam beberapa bagian mengalami pergeseran, berpengaruh besar dalam perkembangan hukum kemudian. Montmorency sampai-sampai menyebutnya dengan "Newton atau Darwin dari ilmu hukum”. Savigny menemukan, seperti yang ditemukan Newton, sebuah dunia fenomena hukum, dan ia bergulat dalam kesulitan yang sebenarnya dari Renaisans. Savigny telah membawa cahaya Renaissans dalam artian memberi pencerahan dalam ilmu hukum. Ia menunjukkan bahwa hukum itu sendiri tunduk pada hukum: hukum bukan ekspresi sewenang-wenang dari pembuat hukum, melainkan hal yang patuh pada proses kosmik. Hukum berevolusi bersamaan dengan bangsa, bahasa, dan budaya. ${ }^{51}$ Perspektif sejarah digunakan Savigny untuk melihat evolusi hukum yang berkelanjutan, agar diketahui "pengetahuan sejati tentang kondisi kita sendiri". ${ }^{52}$

50 Toews, “The Immanent Genesis and Transendent Goal of Law”, hlm. 168.

51 Motnmorency, "Friedrich Carl von Savigny", hlm. 51-52.

52 Zimmermann, “The 'Darwin' of German Legal Theory”, hlm. 106. Meskipun aliran hukum sejarah sering diidentikkan dengan evolusionisme, tidak semua ahli hukum sejarah menawarkan teori evolusi dan tidak semua evolusionis hukum pernah menjadi ahli hukum sejarah. Tulisan Savigny mendahului karya Darwin yang terkenal setengah abad; dia menekankan hukum berevolusi (berkembang) dengan kemajuan peradaban, tetapi dia tidak mengajukan teori evolusi. Brian Z. Tamanaha, "The Unrecognized Triumph of Historical Jurisprudence”, Texas Law Review, 91 (2013), hlm. 625. Tentang evolusi hukum sendiri, E. Donald Elliott membaginya ke dalam empat kelompok: ada yang menggunakan pendekatan sosial; 


\section{Urgensi dan Relevansi Hukum sebagai Manifestasi Jiwa Bangsa}

Bagian ini ingin melihat urgensi pemikiran Savigny dan relevansinya saat ini. Dalam bahasan urgensi akan diuraikan letak penting pemikiran Savigny; sedangkan dalam bahasan relevansi akan dikontekstualisasi pemikiran Savigny yang dihasilkan pada awal abad 19 dengan situasi abad 21, tertama di Indonesia. Hanya dengan penggalian urgensi dan kontekstualisasi relevansi ini maka kearifan pemikiran besar pada masa lampau, sebagaimana yang dihasilkan oleh Savigny, akan menjadi lebih bermakna pada tempat di sini dan waktu sekarang.

Artikel ini, setelah memaparkan intipemikiran dan latarbelakang pemikiran Savigny, mengidentifikasi urgensi pemikiran Sang Tokoh tentanghukum setidaknya terletak dalam duahal: keterpaduanhukum dengan aspek sosial lainnya dan kesinambungan hukum masa lalu, kini, dan mendatang. Pertama, tentang keterpaduan hukum dengan aspek sosial lainnya. Sebagaimana uraian pada bagian terdahulu, hukum dalam pandangan Savigny merupakan satu kesatuan dengan aspek kehidupan sosial lainnya, seperti bahasa, tata krama, dan budaya. Ia bahkan terlepas dari negara, karena hukum memang dijumpai dalam setiap kehidupan sosial masyarakat, termasuk pada saat belum ada negara seperti yang dikenali sekarang. Sebagai salah satu aspek dalam kehidupan sosial, hukum teridentifikasi tidak dibuat secara sengaja, lebih-lebih oleh kekuatan politik tertentu, tetapi muncul dari jiwa bangsa (spirit of the people, volksgeist), dari kesadaran masyarakat.

Pemikiran Savigny yang menyatakan hukum merupakan satu kesatuan dengan berbagai aspek sosial kemasyarakatan, semisal bahasa, ${ }^{53}$ budaya, dan berarti juga bisa politik dan ekonomi,

pendekatan doktrinal; pendekatan ekonomi; dan pendekatan sosiobiologis. Dari keempat kelompok itu, pendekatan sosial adalah yang paling tua, dan Savigny adalah tokoh yang mengawalinya. E. Donald Elliott, "The Evolutionary Tradition in Jurisprudence”, Columbia Law Review, 85 (1985), hlm. 40.

53 Menganalogikan hukum dengan bahasa ini pada satu sisi menujukkan 
menunjukkan bahwa kesemuanya itu merupakan satu kesatuan dalam kehidupan masyarakat. Sebagai satu kesatuan, maka kehidupan umat manusia sesungguhnya memerlukan kesemuanya dan menolak mengabaikan sebagiannya. Dalam bidang hukum, hal ini berarti dibutuhkan suatu pemahaman dan kesadaran bahwa hukum berada dalam satu kesatuan dengan aspek-aspek sosial tadi.

Memahami hukum sebagai satu kesatuan dengan aspek sosial kemasyarakatan lainnya berarti ingin mendudukkan hukum secara holistikdimasyarakat. Denganberhukumsecaraholistik, makahukum hendak diutuhkan atau disatukan (kembali) dengan lingkungan, alam, dan orde kehidupan yang lebih besar. ${ }^{54}$ Dengan begitu, maka apa yang dibentuk, diterapkan, dan ditegakkan sebagai hukum harus dikaitkan dengan aspek sosial budaya dan nilai-nilai yang hidup pada suatu masyarakat. Karena itu, dibutuhkan kemampuan yang baik dari aktor aktor negara cum hukum dalam membaca, memahami, menghayati, dan mempertimbangkan aspek sosial budaya beserta nilai-nilai yang hidup pada masyarakat yang menjadi adresat hukum. Berhukum secara holistik tidak akan membeda-bedakan secara fundamental aspek hukum dengan aspek sosial lainnya, kecuali

hukum, seperti halnya bahasa, berada dalam kesadaran suatu masyarakat, yang tumbuh dan berkembang secara alamiah. Bahasa rakyat bukanlah produk dari "pilihan". Bahasa berkembang secara spontan dan lambat, sebagai bagian organik dari evolusi manusia, dan itu tertanam dalam kehidupan sehari-hari manusia. Demikian juga hukum, bukanlah produk dari pilihan hati nurani; melainkan berkembang secara spontan dan tertanam dalam kehidupan sehari-hari masyarakat. Setiap rakyat (volk) memiliki bahasa khasnya sendiri yang mencerminkan semangat uniknya (volksgeist), sehingga setiap masyarakat pun memiliki hukum khasnya sendiri yang mencerminkan semangatnya (Menachem Mautner, "Three Approaches to Law and Culture”, Cornell Law Review, 96, 4 [2011], hlm. 846). Namun demikian, pada sisi lain, sebagaimana dikatakan Richard A. Posner ("Savigny, Holmes, and the Law and Economic of Possession", Virginia Law Review, 86 [2000], hlm. 537), menganalogikan hukum dengan bahasa juga menunjukkan formalisme. Sebab, bahasa adalah sistem aturan yang tidak bisa dilanggar dengan mengacu pada kebijakan sosial.

54 Satjipto Rahardjo, Hukum dalam Jagat Ketertiban (Jakarta: UKI Press, 2009), hlm. 35. Baca juga: Sudjito, Ilmu Hukum Holistik: Studi Untuk Memahami Kompleksitas dan Pengaturan Pengelolaan Irigasi (Yogyakarta: Gadjah Mada University Press, 2014). 
sebatas karakteristiknya saja. Hal ini disebabkan karena asal muasal kesemuanya itu sebenarnya sama, yaitu jiwa rakyat atau bangsa yang tercermin dalam kesadaran masyarakat.

Berhukum secara holistik ini berbeda dengan berhukum secara skeletonik. Dalam berhukum secara skeletonik, maka hukum akan dibaca, dilihat, dan diperlakukan berbeda-beda secara tegas dengan aspek sosial lainnya. Bahkan, di internal hukum sendiri terjadi demarkasi yang sangat tegas: hukum tata negara, hukum pidana, dan hukum perdata, misalnya..$^{55}$ Karena pembedaan itu, bidang-bidang hukum dan juga aspek-aspek sosial kemasyarakatan lainnya dilihat dan diperlakukan secara otonom dan terpisah. Hukum itu otonom dan terlepas dari aspek sosial lainnya, demikian berhukum secara skeletonik.

Berhukum secara holistik juga membawa konsekuensi bahwa berbagai aspek sosial kemasyarakatan sesungguhnya memiliki peran yang sama urgennya dalam kehidupan masyarakat. Di antara aspek-aspek sosial itu tidak ada yang merasa hierarkinya lebih tinggi dan berperan lebih penting bagi kehidupan masyarakat, apalagi menegasikan yanglainnya. Karenaitu, klaimyang menyatakan hukum sebagai bidang sosial kemasyarakatan yang paling penting, bahkan mendakunya sebagai panglima, sebagaimana sering diungkapkan banyak penstudi hukum, jelas sangat berlebihan! Klaim semacam itu terkesan meremehkan peran penting aspek sosial kemasyarakatan lainnya, seperti politik, ekonomi, adat, budaya, dan agama, yang juga sama-sama menyumbang pada kebaikan dan keadaban suatu masyarakat. Padahal hukum itu, sebagaimana diungkapkan Satjipto Rahardjo, hanya menempati satu sudut saja. ${ }^{56}$

Kedua, pemikiran Savigny urgen dalam hal kesinambungan hukum pada masa lalu, kini, dan mendatang. Sebagaimana uraian bagian terdahulu, Savigny menekankan bahwa hukum harus mencerminkan semangat dan kesadaran masyarakat, yaitu jiwa bangsa (volksgeist, spirit of the people). Hukum dengan demikian merupakan manifestasi jiwa bangsa. Awal mula sikap Savigny ini

55 Rahardjo, Hukum dalam Jagat Ketertiban, hlm. 36.

56 Rahardjo, Hukum dalam Jagat Ketertiban, hlm. 95-107. 
terlihat dari penolakannya terhadap usulan pemberlakuan kode yang seragam bagi seluruh wilayah Jerman dengan cara mengadaptasi Kode Napoleon, yang dinilainya hanya akan menjadikan hukum yang berlaku terlepas atau tidak memiliki keterkaitan dengan jiwa bangsa dan hukum yang hidup pada masyarakat Jerman. Bagi Savigny, keberlanjutan jiwa bangsa yang juga tercermin dan termanifestasikan dalam hukum itu harus terus dijaga. Dengan begitu, akan ada keberlanjutan dan kesinambungan antara hukum pada masa lalu, kini, dan nanti. ${ }^{57}$

Sikap Savigny ini secara relatif konsisten dijumpai dalam karyakaryanya, sekalipun pada akhir bagian terdahulu dari artikel ini juga terungkap adanya pergeseran dalam karya Savigny yang lebih belakangan. Namun demikian, jika diperhatikan lagi akan terlihat bahwa pergeseran itu terkait dengan peran subyek hukum dalam kaitannya dengan masyarakat modern dan negara-bangsa, sehingga apabila sebelumnya subyek itu sepenuhnya ada pada masyarakat maka sekarang juga ada pada negara. Dengan menilai peran penting negara, Savigny ingin mengingatkan bahwa dalam perkembangan

57 Dalam perspektif aliran hukum sejarah, mengupayakan keberlanjutan ini yang dirasa paling sulit. Sebab, jika berpegang teguh pada sesuatu yang ada di masyarakat, maka reformasi dan apalagi revolusi tentu tidak bisa banyak dilakukan. Karena itu, kata Brian $\mathrm{H}$ Bix, aliran sejarah hukum mengalami dilema dalam deskripsi dan preskripsi. Sebagai deskripsi, hukum harus mencerminkan karakter dan jiwa masyarakat (bangsa); sementara sebagai preskripsi hukum bertindak mengarahkan dan memberi petunjuk pada perubahan sosial. Brian H. Bix, "A New Historical Jurisprudence?", Washington University Law Review, 95 (2018), hlm. 1036. Kesulitan ini yang nampaknya diakomodasi oleh aliran hukum yang masih berjejak pada ranah sosiologis-historis, namun juga mendorong hukum untuk mengarahkan dan memberi petunjuk pada perubahan sosial, yaitu sociological jurisprudence. Sebagaimana dikatakan Roscoe Pound, sejarah hukum menunjukkan bagaimana hukum masa lalu tumbuh dari kondisi sosial, ekonomi, dan juga psikologis, sehingga hukum itu sesuai dengan atau mengakomodasi kebutuhan pada saat itu. Karena itu, berarti juga dapat diperlakukan, dalam konteks sekarang, seberapa jauh hukum pada masa lampau itu dilanjutkan, atau sebaliknya diabaikan, sesuai dengan konteks sosial dan harapan-harapan yang diinginkan. Roscoe Pound, "The Scope and Purpose of Sociological Jurisprudence, (Concluded) III”, Harvard Law Review, 25, 6 (1912), hlm. 514-515. 
masyarakat modern diperlukan kesadaran sejarah dari aktornya, dalam hal ini terutama negara.

Dengan begitu, aliran hukum sejarah Savigny memiliki urgensi dalam menjaga kesatuan hukum dengan aspek sosial kemasyarakatan dan mengupayakan keberlanjutan hukum dengan jiwa bangsa. Refleksi kesejarahan tentang hukum dari Savigny memungkinkan suatu bangsa untuk melihat sejarahnya sebagai referensi yang sejati (genuine). Kesejarahan dalam hal ini tidak selalu bermakna masa lampau saja, melainkan berjalan bersama waktu, entah dulu, kini, maupun masa yang akan datang. ${ }^{58}$ Karena itu, pemikiran Savigny tentang hukum memiliki dua makna: hukum adalah produk masyarakat dan hukum terus berkembang sehubungan dengan perubahan dalam masyarakat. Hukum, oleh karena itu, membawa jejak yang tak terhapuskan dari sejarah masyarakat. ${ }^{59}$

Dua hal yang disebut sebagai urgensi dari pemikiran Savigny dalam artikel ini menjadikannya sebagai kekhasan dari Savigny, yang secara akademis kemudian dikategorisasi sebagai aliran hukum tersendiri, yaitu aliran hukum sejarah (historical jurisprudence). Labelisasi "(ilmu) hukum sejarah" bisa memberi kesan bahwa sejarah hukum sebagai inti teori. Padahal aliran ini bermaksud untuk melihat dan menjelaskan hubungan antara hukum dan keadaan sosial dan ekonomi suatu masyarakat. Teori atau aliran hukum ini menyatakan bahwa hukum adalah produk dari sejarah masyarakat. Karena itu dalil ini sesungguhnya terpisah dari sejarah hukum sebagai bidang akademik, ${ }^{60}$ yang lebih melihat perkembangan hukum secara sinkronik dan diakronik.

Dalam diskursus ilmu hukum, aliran hukum sejarah, dengan Savigny sebagai tokoh utamanya, mendapat perhatian tersendiri. Ia bersama-sama dengan aliran hukum kodrat atau alam, aliran hukum positivisme, dan aliran hukum realisme, menjadi bahan kajian dan

58 Antonius Cahyadi, "Hukum Rakyat ala Friedrich Karl von Savigny”, Jurnal Hukum dan Pembangunan, 35, 4 (2005), hlm. 388.

59 Brian Z. Tamanaha, "The Third Pillar of Jurisprudence: Social Legal Theory”, William \& Mary Law Review, 56, 6 (2015), hlm. 2246.

60 Tamanaha, "The Unrecognized Triumph", hlm. 623. 
bahasan yang nampaknya selalu ditemui dalam studi hukum lanjut (pascasarjana). Dalam buku-buku teori hukum dan filsafat hukum, ${ }^{61}$ keempat aliran hukum ini bersama variannya selalu dijumpai dalam pokok bahasannya. Hal ini menunjukkan aliran-aliran hukum tersebut, dan aliran hukum sejarah (Savigny) sebagai bagiannya, dipandang urgen dalam membaca, memahami, dan menyikapi perkembangan sosial kemasyarakatan, sehingga selalu dibahas, dipelajari, diajarkan, dan disebarluaskan.

Apabila pemikiran Savigny dipandang demikian urgen, lalu bagaimana sebenarnya relevansinya dalam perkembangan masyarakat hari ini. Pertama-tama harus disampaikan, situasi zaman saat Savigny menyampaikan pandangannya itu tentu berbeda dengan saat ini. Keberbedaan itu sudah terlihat dalam organisasi sosial kemasyarakatan, di mana dulu negara dan nasionalisme (khususnya Jerman) masih mencari bentuknya yang definitif, sementara sekarang yang disebut negara beserta kedaulatan dan kekuasaannya sudah demikian jelasnya. Begitu pula dengan hubungan antar masyarakat yang sekarang ini semakin ekspansif dan mengglobal, antara lain karena hasrat memenuhi dan memuaskan kebutuhan ekonomi yang didukung oleh kemajuan teknologi. Ini artinya, kompleksitas yang dihadapi masyarakat hari ini semakin lebih terasa terutama dalam kaitannya dengan skala wilayah yang global, meskipun juga harus dikatakan setiap zaman menghadapi tantangannya tersendiri.

Pada saat Savigny menyampaikan pendapatnya, tantangan yang dihadapi lebih berupa adanya usulan membentuk kode di Jerman yang berlaku secara nasional-universal, sementara kondisi riilnya masyarakat memberlakukan hukum secara lokal. Ekspansi ekonomi sendiri pada saat itu baru saja dimulai, yaitu setelah Revolusi Perancis. Ini berarti situasinya sedang transisional, dari masyarakat yang feodal

61 Teori hukum dan filsafat hukum di sini dimaksudkan sebagai hasil pemikiran, yang dibedakan dengan teori hukum dan filsafat hukum sebagai proses. Sebagai hasil pemikiran, maka teori hukum dan filsafat hukum memelajari teori-teori hukum dan filsafat-filsafat hukum yang dihasilkan oleh pemikirpemikir terdahulu dan berpengaruh dalam peradaban masyarakat. Sebagai proses, teori hukum dan filsafat hukum berupaya berteorisasi dan berfilsafat tentang fakta sosial dari sudut ilmu hukum. 
menuju masyarakat yang borjuis. Dalam keadaan yang demikian, Savigny berpendapat bahwa hukum tidak boleh tercerabut dari semangat rakyat, dari jiwa bangsa. Membentuk hukum yang berlaku secara nasional-universal, dan lebih-lebih jika mengadopsi begitu saja hukum Perancis, dianggap akan memisahkan hukum yang diberlakukan dari jiwa bangsa yang lebih bersifat lokal-khas.

Tantangan tersebut jelas terlihat berbeda pada hari ini. Pada masa sekarang, realitas global berupa kehidupan antar umat, bangsa, dan negara yang saling berketergantungan, menuntut adanya kesadaran global (global consciousness) pula. ${ }^{62}$ Dalam bidang hukum, hal ini berarti mendorong kesadaran hukum secara global untuk memberlakukan norma hukum yang memiliki karakter dan perspektif global-universal. Realitas ini dengan mudah dapat diamati pada keterkaitan dan keterikatan negara-negara dengan berbagai perjanjian internasional, yang sudah menjadi keniscayaan. Akibatnya, negara tidak lagi betul-betul mandiri dalam membentuk hukumnya, tetapi harus mengakomodasi dan menyesuaikan dengan isi perjanjian internasional. ${ }^{63}$ Karena itu, kesadaran masyarakat dan jiwa bangsa yang dalam konteks bangsa dan negara hari ini berbatas wilayah nasional, akan sangat mungkin diabaikan dalam pembentukan hukum nasional, disebabkan keharusan mempertimbangkan kesesuaiannya dengan isi perjanjian yang diratifikasi. Hal ini menunjukkan bahwa spirit of the people atau volksgeist potensial diabaikan dalam berhukum saat ini.

62 Joas Adiprasetya, Mencari Dasar Bersama: Etik Global dalam Kajian Postmodernisme dan Pluralisme Agama (Jakarta: Gunung Mulia dan UPI STT Jakarta, 2002), hlm. 36.

63 Keterkaitan suatu negara dengan dunia internasional memang menjadi sebab negara menjadi tergerus kedaulatan dan otonominya dalam membentuk hukum dan kebijakan nasionalnya, sehingga menjadi tidak lagi semata-mata mempertimbangkan apa yang menjadi jiwa bangsa. Keterkaitan suatu negara dengan dunia internasional itu ada yang melalui organisasi internasional, perusahan multinasional, sistem negosiasi interorganisasi dan proses standarisasi global, asosiasi global, dana global, dan LSM internasional. Lihat: Dian Rositawati, "Kedaulatan Negara dalam Pembentukan Hukum di Era Globalisasi”, dalam Hukum yang Bergerak: Tinjauan Antrpologi Hukum, ed. Sulistyowati Irianto (Jakarta: Yayasan Obor Indonesia, 2009), hlm. 43-59. 
Dengan mempertimbangkan konteks tantangan zaman yang dihadapi itu, artikel ini menilai pemikiran Savigny pada masa sekarang ini relevan dalam dua hal. Pertama, hukum saat ini yang terlihat berkarakter atau berperspektif global-universal perlu diimbangi dengan nilai-nilai lokal-nasional melalui jiwa bangsa. Dalam pembangunan hukum yang tampak lebih berperspektif global-universal, maka jiwa bangsa akan memberi warna pada sistem hukum nasional, ${ }^{64}$ termasuk Indonesia. Dengan adanya warna jiwa bangsa pada hukum nasional, maka diharapkan ada keberlanjutan dan kesinambungan pada hukum yang telah, sedang, dan akan berlaku. ${ }^{65}$

Relevansi yang demikian itu akan terlihat dalam melihat perkembangan sistem hukum nasional dan jiwa bangsa di Indonesia, sebagaimana akan diuraikan berikut. Di Indonesia, apa yang menjadi jiwa bangsa tidak lain adalah Pancasila. Labelisasi ini didasari pertimbangan bahwa nilai-nilai yang terkandung dalam Pancasila merupakan, sebagaimana disebut Yudi Latif, "kekayaan kerohanian, kepribadian, dan wawasan kebangsaan”. Kekayaan kebangsaan ini ada dan dimiliki oleh masyarakat nusantara, namun karena penjajahan, "terpendam lumpur sejarah". ${ }^{66}$ Istilah yang digunakan Soekarno ketika mendapatkan apresiasi atas sambutannya tentang dasar negara dalam suatu kepanitian kemerdekaan menggambarkan kekayaan tersebut benar-benar ada dalam pengalaman masyarakat nusantara dan bukan buatan, "saya bukan pencipta, saya sekadar penggali" ${ }^{67}$

Ungkapan demikian menunjukkan bahwa Pancasila memiliki

64 Aspirasi semacam ini bisa mengesankannya sebagai bagian dari paradoks global (global paradox), bahwa "semakin manusia dipaksa hidup dalam dunia yang mengglobal, semakin ia merasa kehilangan jati diri dan semakin pula ia berusaha keras memegang jati diri kulturalnya”. Adiprasetya, Mencari Dasar Bersama, hlm. 36.

65 Lihat kembali catatan kaki nomor 5 , yang menunjukkan bahwa keberlakuan hukum adat di Indonesia dalam hal tertentu dimungkinkan karena adanya pengaruh pemikiran hukum yang harus selaras dengan jiwa bangsa dan berkelanjutan ini.

66 Yudi Latif, Negara Paripurna: Historisitas, Rasionalitas, dan Aktualitas Pancasila (Jakarta: Gramedia Pustaka Utama, 2011), hlm. 4.

67 Latif, Negara Paripurna, hlm. 20-21. 
dimensi realitasnya. Dengan dimensi realitas, maka nilai-nilai yang terkandung di dalamnya berarti memiliki akar sejarahnya dalam masyarakat dan bangsa Indonesia, sekaligus juga menunjukkannya hidup dalam pengalaman masyarakat dan bangsa, sekalipun dalam perkembangan kemudian terpendam lumpur sejarah. Karena itu dapat dikatakan, dalam konteks bangsa dan negara Indonesia, Pancasila merupakan jiwa bangsa. ${ }^{68}$

Dalam konteks negara-bangsa, nilai-nilai dalam Pancasila yang merupakan dasar negara dijabarkan lebih lanjut dalam Konstitusi, Undang-Undang Dasar Negara Republik Indonesia Tahun 1945. Dalam bernegara hukum, isi dan amanat Konstitusi itu dijabarkan lebih lanjut dalam undang-undang beserta peraturan di bawahnya. Karena itulah, apa yang menjadi norma hukum dalam undangundang beserta peraturan di bawahnya harus sinkron dengan Konstitusi, berarti pula Pancasila, yang dalam konteks artikel ini disebut jiwa bangsa. Dengan demikian, dalam undang-undang dan peraturan di bawahnya itu akan diketahui apakah pembentukannya telah mempertimbangkan Konstitusi (dan Pancasila sebagai jiwa bangsa).

Pada pembentukan undang-undang misalnya, dapat dikatakan bahwa setiap inisiasinya baik oleh Presiden atau Dewan Perwakilan

68 Dalam konteks Indonesia, penyematan Pancasila sebagai volksgeist sering dipertanyakan, sama halnya dengan penyematannya sebagai grundnorm. Sebagaimana dijelaskan Shidarta, hal itu disebabkan karena kedua istilah ini diserap dari bahasa asing. Melabeli Pancasila sebagai grundnorm berarti menjadikannya sebagai nilai atau asas dan norma yang apriori, bermakna benar dengan sendirinya; sementara menyebutnya sebagai volksgeist berarti menjadikannya sebagai nilai atau asas dan norma yang aposteriori, bermakna adanya itu melalui pengalaman empiris dan dilakoni sebagai tradisi, sehingga tidak bisa dipersangkakan ada. Bagi Shidarta, penyempatan Pancasila sebagai volksgeist sesungguhnya suatu penempatan tentang konteks pencarian (context of discovery) Pancasila, yang berbeda dengan konteks justifikasinya (context of justification), yang merupakan bagian dari sistem norma hukum positif, yang biasanya menggunakan labelisasi norma fundamental (staatsfundamentalnorm), suatu istilah dari Hans Nawiasky yang memodifikasi grundnorm-nya Hans Kelsen. Shidarta, “Pancasila itu 'Grundnorm' atau 'Volksgeist'?”, https: / / business-law.binus. ac.id/2019/07/06/pancasila-itu-grundnorm-atau-volksgeist/, 6/7/2019, diakses $2 / 2 / 2020$. 
Rakyat mengharuskan untuk mempertimbangkan kesesuaiannya dengan Pancasila dan Konstitusi, sebagaimana umumnya terbaca dari Naskah Akademik pembentukannya terutama pada bagian landasan filosofis, meskipun hal ini juga tidak menjamin akan ada kesesuaian sepenuhnya. Namun demikian, pada undang-undang yang dibentuk karena keharusan mengakomodasi isi perjanjian internasional, sebagian besar bahkan tidak ada Naskah Akademiknya, yang berarti tidak terbaca apakah mempertimbangkan kesesuaiannya dengan Konstitusi atau tidak. ${ }^{69}$ Pada perjanjian internasional yang meniadakan negara peserta untuk mereservasi, hal demikian terlihat lebih jelas, karena isi undang-undang bahkan harus sesuai dengan standar minimal yang ada dalam perjanjian internasional, seperti pada bidang hak kekayaan intelektual.

Fakta demikian mengesankan jiwa bangsa dan alasan-alasan lainnya yang sifatnya lokal-nasional seolah tidak lagi penting dalam berhukum yang berperspektif global-universal dan melewati batasbatas teritorial kedaulatan. Dalam artikel ini justru dipandang sebaliknya, kenyataan demikian harus dijadikan refleksi diri dalam membentuk hukum dan berhukum, agar mempertimbangkan pula "kekayaan kerohanian, kepribadian, dan wawasan kebangsaan" sehingga sejalan dengan karakter bangsa dan negara. Terlebih lagi dalam kehidupan yang global-universal tetap tidak menegasikan peran negara, karena negara tetap dipandang sebagai pemegang kedaulatan tertinggi. Dengan demikian, dalam berhukum yang berperspektif global-universal sekalipun, penguatan dan pewarnaan sistem hukum nasional diperlukan, dan dalam konteks Savigny dilakukan melalui kesesuaiannya dengan jiwa bangsa.

Kedua, dalam kaitannya dengan semakin ekstensifnya instrumentasi hukum nasional untuk mendukung dan melayani pembangunan suatu negara, pemikiran Savigny relevan agar fungsionalisasi hukum yang demikian itu menjadikan pembangunan

69 Hikmahanto Juwana, "Kewajiban Negara dalam Proses Ratifikasi Perjanjian Internasional: Memastikan Keselarasan dengan Konstitusi dan Mentransformasikan ke Hukum Nasional”, Undang: Jurnal Hukum, 2, 1 (2019), hlm. 10. 
nasional lebih terarah. Dalam hal ini, pemberian arah pembangunan dengan bersaranakan hukum ini diupayakan melalui hukum yang mencerminkan dan sejalan dengan jiwa bangsa.

Pembacaan relevansi demikian didasari pertimbangan bahwa realitas hukum hari ini, tidak disangsikan lagi, lebih bermuatan norma yang ditujukan untuk menunjang sesuatu yang ingin diraih dan dicapai oleh negara, yaitu pembangunan. Kehendak dan ego pembangunan seringkali memaksa diadakannya norma hukum yang sama sekali baru bagi suatu masyarakat. Hukum menjadi sarana pembangunan, sehingga harus menunjang pula pembangunan. Dalam situasi semacam itu justru penting menempatkan pembangunan tidak sampai berorientasi pembangunan semata, dan norma-norma hukum juga sebatas mengikuti kehendak-kehendak pembangunan, melainkan bagaimana agar pembangunan menjadi terarah. ${ }^{70}$

Dalam konteks pemikiran Savigny, mengarahkan dan memagari pembangunan yang diselenggarakan itu diupayakan melalui penyesuaian dan penyelarasan hukum dengan jiwa bangsa. Karena itu, artikel ini menegaskan, pemikiran bahwa hukum merupakan manifestasi jiwa bangsa relevan pada situasi sekarang dalam upaya membangun hukum yang sejalan dan dilandasi oleh jiwa bangsa. Kalaupun realita hukum yang dikembangkan lebih untuk melayani pembangunan, pemikiran demikian berkontribusiagarpembangunan yang dikehendaki itu menjadi lebih terarah.

Dengan urgensi dan relevansinya itu, pemikiran Savigny pada masa sekarang tentu juga menghadapi tantangan dan konsekuensinya. Hal ini terutama terkait dengan bentuk dari jiwa bangsa itu sendiri atau yang merepresentasikannya. Identifikasi demikian dalam konteks negara-bangsa Indonesia jelas bukan pekerjaan mudah. Sebagai negara yang berbineka dan multikultur, bentuk dan representasi dari jiwa bangsa itu sendiri di Indonesia berarti bisa

70 Tentang hukum dan pembangunan dalam konteks Indonesia, dapat dibaca artikel Ulasan Tokoh dan Pemikiran Hukum pada edisi sebelumnya dalam jurnal ini: M. Zulfa Aulia, "Hukum Pembangunan dari Mochtar Kusuma-atmadja: Mengarahkan Pembangunan atau Mengabdi pada Pembangunan?”, Undang: Jurnal Hukum, 1, 2 (2018): 363-392. 
beragam, meskipun kalaupun beragam tetap pula harus dikatakan kesemuanya sebagai kekayaan kebangsaan. Dalam kenyataan jiwa bangsa yang beragam disebabkan disesuaikan dengan kekayaan yang hidup pada masyarakat yang memang plural, sementara hukum harus tampil mencerminkannya, maka hal ini bisa berkonsekuensi pada pluralisme hukum. Konsekuensi ini menjadi berbeda apabila jiwa bangsa dalam konteks Indonesia ditempatkan sebagai jiwa bangsa dalam kaitannya dengan negara-bangsa dan nasionalisme, sehingga akan ada pemilahan dan pencampur-adukan dari jiwa bangsa yang beragam itu sebagai jiwa bangsa yang dikualifikasi nasional. Dalam hal yang disebut terakhir, akan ada proses prismatisasi dan refleksi tentang jiwa bangsa yang nasional ini, dan dalam hukum akan berujung pada unifikasi hukum.

Karena itulah, memandang penting dan relevan jiwa bangsa dalam kaitan bernegara hukum saat ini, terutama bagi negara-bangsa yang berbineka seperti Indonesia, akan bisa berakibat pada pilihanpilihan yang dilematis: unifikasi atau pluralisme hukum. Dilema ini pula yang tampaknya menjadikan politik hukum Indonesia menjalankan keduanya beriringan, suatu "unifikasi dan kodifikasi parsial". ${ }^{71}$ Dengan politik hukum demikian, unifikasi diupayakan terhadap bidang-bidang yang dianggap netral dari segi kultur, keagamaan, dan sistem sosial, sedangkan bidang-bidang yang tidak netral akan ditangguhkan atau dibiarkan tetap plural. Dalam hal pluralisme, maka identifikasi bentuk atau representasi jiwa bangsa barangkali lebih mudah dilakukan, karena disesuaikan dengan apa yang menjadi semangat dan kekayaan hidup pada masing-masing satuan masyarakat yang plural. Sebaliknya, dalam hal unifikasi, maka identifikasinya akan bermuara pada pilihan-pilihan sulit: mana yang kemudian direfleksikan sebagai jiwa bangsa yang nasional. Dalam hal yang disebut terakhir, artikel ini dengan tidak mendiskusikannya lebih lanjut di sini berpandangan bahwa strategi penyerbukan silang antarbudaya (cross cultural fertilization) barangkali bisa dipinjam dan

71 Sunaryati Hartono, Bhinneka Tunggal Ika sebagai Asas Hukum bagi Pembangunan Hukum Nasional (Bandung: Citra Aditya Bakti, 2006), hlm. 2425. 


\section{Zulfa Aulia}

digunakan untuk mengidentifikasinya, yaitu menyerbukkan budayabudaya lokal yang ada untuk mendapatkan budaya bangsa yang unggul. ${ }^{72}$ Namun demikian hal ini juga bisa sama dilematisnya, karena dengan begituberartijiwabangsa telah mengalamiperubahan bentuk, yaitu menjadi semacam prisma, sehingga keinginan menampilkan apa yang ada dalam realitas sosial bisa jadi justru merupakan bagian dari agenda menunjukkan apa yang seharusnya. ${ }^{73}$

\section{E. Kesimpulan}

Artikel ini telah mengungkap bahwa pemikiran Savigny tentang hukum dilatarbelakangi oleh responsnya terhadap perkembangan hukum di Jerman awal abad 19. Sebagai negara yang belum definitif dan sedang mencari bentuk nasionalismenya, Jerman pada saat itu belum memiliki sistem hukum yang menyeluruh dalam artian menasional, melainkan hukum yang terpisah-pisah pada Negara Bagian dan berlaku secara lokal. Savigny menolak usulan untuk membentuk (atau lebih tepatnya mengimpor) hukum yang berlaku secara universal, sebab dalam refleksi historisnya diketahui bahwa hukum itu tumbuh secara alamiah di masyarakat dan tidak dibuat secara sengaja. Hukum menjadi bagian dari kehidupan sosial masyarakat yang dapat dilihat dalam wujud perilaku masyarakat, seperti juga bahasa dan tata krama. Ia menjadi satu kesatuan dengan aspek sosial lainnya, berasal dari kesadaran masyarakat dan jiwa bangsa (spirit of the people, volksgeist), dan karena itu hukum dikatakan sebagai manifestasi jiwa bangsa. Dalam perkembangannya, pemikiran ini mengalami pergeseran, bahwa, selain rakyat atau masyarakat itu sendiri, negara juga menjadi subyek yang berperan penting dalam mengaktualisasikan kesadaran masyarakat dan jiwa bangsa.

Pemikiran Savigny ini memiliki urgensi dalam mendudukkan

72 Aan Rukmana dan Eddie Lembong, "Penyerbukan Silang Antar Budaya”, dalam Penyerbukan Silang Antarbudaya: Membangun Manusia Indonesia, ed. Sahrul Mauludi (Jakarta: PT Elex Media Komputindo bekerjasama dengan Yayasan Nabil, 2015), hlm. lix-lx.

73 Goenawan Mohamad, Seni, Politik, Pembebasan (Yogyakarta: IRCiSoD, 2018), hlm. 172. 
hukum secara holistik di masyarakat, sehingga dalam membangun hukum perlu dikaitkan dan diselaraskan dengan aspek sosial budaya beserta nilai-nilai yang hidup pada masyarakat. Ia juga urgen dalam upaya menjaga kesinambungan hukum masa lalu, kini, dan mendatang, dalam hal ini melalui penyesuaian hukum dengan jiwa bangsa. Dalam konteks sekarang, di mana hukum suatu negara lebih berkarakter dan berperspektif global-universal, pemikiran Savigny dipandang relevan dalam upaya menjaga agar hukum nasional punya warna semangat, kesadaran, dan sejarah bangsa, yaitu sebagaimana yang menjadi jiwa bangsanya. Ia juga dipandang relevan, agar penggunaan hukum yang saat ini terlihat untuk melayani pembangunan suatu negara, juga dapat mengarahkan dan memagari apa yang diikhtiarkan sebagai pembangunan itu. Dengan begitu, Savigny berkontribusi besar bagi pembangunan hukum yang tidak sekadar bisa menjawab tantangan zaman, melainkan juga sejalan dengan jiwa bangsa.

\section{Daftar Pustaka}

Adiprasetya, Joas. Mencari Dasar Bersama: Etik Global dalam Kajian Postmodernisme dan Pluralisme Agama. Jakarta: Gunung Mulia dan UPI STT Jakarta, 2002.

Basuki, Zulfa Djoko. "Mazhab Sejarah dan Pengaruhnya terhadap Pembentukan Hukum Nasional”. Dalam Filsafat Hukum: Mazhab dan Refleksinya, diedit oleh Lili Rasjidi dan B. Arief Sidharta, 3046. Bandung: Remaja Rosdakarya, cetakan kedua, 1994.

Berkowitz, Roger. "From Justice to Justification: An Alternative Genealogy of Positive Law”. UC Irvine Law Review, 1, 3 (2011): 611-630.

Bix, Brian H. "A New Historical Jurisprudence?”. Washington University Law Review, 95 (2018): 1035-1047.

Blackbourn, David. "Germany and the Birth of the Modern World, 1780-1820". Bulletin of the German Historical Institute, 51 (2012): 9-21.

Bogdan, Michael. Pengantar Perbandingan Sistem Hukum. Terjemah 
oleh Derta Sri Widowatie. Bandung: Nusa Media, 2010.

Cahyadi, Antonius. "Hukum Rakyat ala Friedrich Karl von Savigny". Jurnal Hukum dan Pembangunan, 35, 4 (2005): 386-406. DOI: 10.21143/jhp.vol35.no4.1466.

Dilcher, Gerhard. "The Germanist and the Historical School of Law:

German Legal Science between Romanticism, Realism, and Rationalism". Zitiervorschlag: Rechtsgeschichte - Legal History Rg 24 (2016): 20-72. DOI: 10.12946/rg24/020-072.

Elliott, E. Donald. "The Evolutionary Tradition in Jurisprudence". Columbia Law Review, 85 (1985): 38-94.

Friedrich, Carl Joachim. Filsafat Hukum: Perspektif Historis. Terjemah oleh Raisul Muttaqien. Bandung: Nusa Media, cetakan keempat, 2014.

Hartono, Sunaryati. Bhinneka Tunggal Ika sebagai Asas Hukum bagi Pembangunan Hukum Nasional. Bandung: Citra Aditya Bakti, 2006.

Hoeflich, Michael H. "Savigny and His Anglo-American Disciples". The American Journal of Comparative Law, 37, 1 (1989): 17-37. Juwana, Hikmahanto. "Kewajiban Negara dalam Proses Ratifikasi Perjanjian Internasional: Memastikan Keselarasan dengan Konstitusi dan Mentransformasikan ke Hukum Nasional". Undang: Jurnal Hukum, 2, 1 (2019): 1-32. DOI: 10.22437/ ujh.2.1.132.

Klenner, Herman. "Savigny’s Research Program of the Historical School of Law and its Intellectual Impact in $19^{\text {th }}$ Century Berlin". The American Journal of Comparative Law, 37, 1 (1989): 67-80.

Kutner, Luis. "Legal Philosophers: Savigny: German Lawgiver". Marquette Law Review, 55, 2 (1972): 280-295.

Latif, Yudi. Negara Paripurna: Historisitas, Rasionalitas, dan Aktualitas Pancasila. Jakarta: Gramedia Pustaka Utama, 2011.

Lay, Cornelis. "Nasionalisme dan Negara Bangsa". Jurnal Ilmu Sosial dan Ilmu Politik, 10, 2 (2006): 165-180. DOI: 10.22146/jsp.11017.

Mautner, Menachem. "Three Approaches to Law and Culture". Cornell Law Review, 96, 4 (2011): 839-67.

Mollnau, Karl A. "The Contributions of Savigny to the Theory of 
Legislation". The American Journal of Comparative Law, 37, 1 (1989): 81-93.

Mohamad, Goenawan. Seni, Politik, Pembebasan. Yogyakarta: IRCiSoD, 2018.

Montmorency, J.E.G. de. "Friedrich Carl von Savigny". Journal of the Society of Comparative Legislation, 11, 1 (1910): 32-54.

Posner, Richard A. "Savigny, Holmes, and the Law and Economic of Possession”. Virginia Law Review, 86 (2000): 535-67.

Pound, Roscoe. "The Scope and Purpose of Sociological Jurisprudence, (Concluded) III”. Harvard Law Review, 25, 6 (1912): 489516.

Rahardjo, Satjipto. Hukum dalam Jagat Ketertiban. Jakarta: UKI Press, 2009.

Reimann, Mathias. "Nineteenth Century German Legal Science". Boston College Law Review, 31, 4 (1990): 837-97.

Republik Indonesia, Badan Pengembangan dan Pembinaan Bahasa Kementerian Pendidikan dan Kebudayaan. Kamus Besar Bahasa Indonesia. Https: / kbbi.kemdikbud.go.id. Diakses 10/4/2020.

Rodes, Robert E. "On the Historical School of Jurisprudence". The American Journal of Jurisprudence, 49 (2004): 165-84.

Rositawati, Dian. "Kedaulatan Negara dalam Pembentukan Hukum di Era Globalisasi”. Dalam Hukum yang Bergerak: Tinjauan Antrpologi Hukum, diedit oleh Sulistyowati Irianto, 43-59. Jakarta: Yayasan Obor Indonesia, 2009.

Rukmana, Aan dan Eddie Lembong. "Penyerbukan Silang Antar Budaya”. Dalam Penyerbukan Silang Antarbudaya: Membangun Manusia Indonesia, diedit oleh Sahrul Mauludi, xxxix-lxv. Jakarta: PT Elex Media Komputindo bekerjasama dengan Yayasan Nabil, 2015.

Savigny, Frederick Charles von. Of The Vocation of Our Age for Legislation. Terjemah oleh Abraham Hayward. London: Littlewood \& Co. Old Bailey.

Savigny, Friedrich Carl von. System of the Modern Roman Law Vol. 1. Terjemah oleh William Holloway. Madras: J. Hingginbotham Publisher, 1867. 
Shidarta. "Pancasila itu 'Grundnorm' atau 'Volksgeist'?". Https: / / business-law.binus.ac.id/2019/07/06/ pancasila-itugrundnorm-atau-volksgeist/, 6/7/2019. Diakses 2/2/2020.

Sudjito. Ilmu Hukum Holistik: Studi Untuk Memahami Kompleksitas dan Pengaturan Pengelolaan Irigasi. Yogyakarta: Gadjah Mada University Press, 2014.

Tamanaha, Brian Z. "The Third Pillar of Jurisprudence: Social Legal Theory”. William \& Mary Law Review, 56, 6 (2015): 2235-77.

Tamanaha, Brian Z. "The Unrecognized Triumph of Historical Jurisprudence”. Texas Law Review, 91 (2013): 615-632.

Toews, John E. "The Immanent Genesis and Transendent Goal of Law: Savigny, Stahl, and the Ideology of the Christian German State". The American Journal of Comparative Law, 37, 1 (1989): 139-169.

Twining, William. General Jurisprudence: Understanding Law from a Global Perspective. Cambridge: Cambridge University Press, 2009.

Watson, Alan. Legal Transplants: An Approach to Comparative Law. Athens, University of Georgia Press, edisi kedua, 1993.

Zimmermann, Augusto. “The 'Darwin' of German Legal TheoryCarl von Savigny and the German School of Historical Law". Journal of Creation, 27, 2 (2013): 105-111. 